\title{
Penegakan Hukum Dalam Wawasan Kebijakan Negara
}

\author{
Oleh : Sutadi Djojokusuma
}

Asisten Menteri Negara Perencanaan Pembangunan Nasional/Ketua Bappenas,

Bidang Pembangunan Hukum, Kemasyarakatan dan Hubungan Kelembagaan.

Masalah penegakan hukum merupakan masalah yang menarik karena berkaitan dengan hukum dan manusia, ' masalah penegakan hukum mempunyai arti penting bagi penyelenggaraan tugas pemerintahan dan pembangunan sekaligus merupakan upaya meninggalkan kualitas sumberdaya manusia dalam bidang hukum. Pembangunansumberdaya manusia adalah upaya untuk membangun manusia Indonesia seutuhnya dan masyarakat Indonesia seluruhnya, yang tidak lain adalah hakikatnya pembangunan nasional sebagai pengamalan Pancasila. Dalam kaitan ini GBHN berbicara mengenai manusia sebagai insan, yang harus kita bangun kehidupannya, harkat dan martabatnya. GBHN jüga berbicara mengenai manusia sebagai sumberdaya pembangunan yang harus terus ditingkatkan kualitas dan kemampuannya untuk membangunan dirinya.

Dalam PJP II, GBHN mengamanatkan bahwa sasaran pembangunan adalah menciptakan kualitas manusia dan masyarakat Indonesia yang maju dan mandiri. Suatu bangsa akan maju " dan mandiri kalau manusianya berkualitas dan ekonominya kokoh. Oleh karena itu GBHNmeletakkan titikberat pembangunan pada bidang ekonomi, seiring dengan peningkatan sumberdaya manusia. Suatu bangsa akan dikatakan semakin maju apabila tingkat pendapatannya semakin tinggi dan pemerataan pendapatannya semakin baik. Suatu bangsa dikatakan lebih maju apabila berbagai indikator sosial dan ekonomi yang dapat dijadikan ukuran adanya kemajuan suatu bangsa terus menunjukkan perbaikan yang makin nyata. Suatu bangsa dikatakan semakin mandiri apabila bangsa tersebut semakin mampu memelihara kehidupannya dan melanjutkan pembangunan dengan kekuatan sendiri. Untuk ini antara lain diperlukan tenagatenaga profesional yang kualitasnya tinggi dan dalam jumlah yang makin memadai untuk memenuhi kebutuhan dan tuntunan pembangunan.

Kemajuan dan kemandirian disamping merupakan kondisi atau tahap perkembangan suatu bangsa, juga mencerminkan sikap suatu bangsa terhadap 'dirinya, masyarakatnya serta tantangan dan masalah-masaha yang dihadapinya dan upaya untuk mengatasinya. Dengan demikian kemajuandan kemandirian selain merupakan wujud kondisi ekonomi, cermin budaya manusia dan masyarakatnya juga merupakan cermin dari hukum dan pranata hukum yang berlaku dalam masyarakat, karenakehidupan hukum merupakan bagian dari budaya hidup masyarakat. Hukum harus dapat menampung atau menjadi wadah dinamika masyarakat yang terus ber̀gerak maju dan harus dapat merekayasa ketertiban dan kesejahteraan masyarakat, sebagai ungkapan kemajuan dan 
kemandirian.

\section{Pesan GBHN}

Dalam kaitan ini, selain hal-hal umum yang telah saya jelaskan di atas mengenai peningkatankualitas sumberdaya manusia, saya ingin menyampaikan beberapa pesan pokok GBHN 1993 dalam bidang hukum, hanya untuk mengingatkan saja bagi saudara-saudara. Pesan pertama adalah pengertian hukum. Menurut GBHN 1993 mengacu kepada UUD 1945 Hukum Nasional adalah sarana ketertiban dan kesejahteraan masyarakat yang berintikan keadilan dan kebenaran. Hukum adalah sarana atau alat; bukan tujuan. Hukum adalah sarana untuk mendatangkan ketertiban dan merekayasa kesejahteraan. Ketertiban" menunjuk kepada sifat hukum yang mengatur dan "kesejahteraan" menunjuk kepada sifat hukum yang membangun.

Pesan kedua dari GBHN 1993, bahwa hukum yang berintikan keadilan dan kebenaran harus mampu menjamin kepastian, ketertiban, penegakan, perlindungan hukum, serta mampu mengamankan dan mendukung pembangunan nasional, atau dengan kata lain mampu, berperan mengayomi masyarakat serta mengabdi pada kepentingan nasional.

Pesan ini sangat erat kaitannyạ dengan pesan tentang pengertian pokok hukum tersebut di atas, yaitu sebagai saraná ketertiban dan kesejahteraan, yang kalau kita uraikan lebih lanjut hukum harus dapat dijadikan dasar untuk menjamin agar masyarakat dapat menikmati kepastian, ketertiban dan perlindungan hukum, menumbuhkan dan mengembangkan disiplin nasional, kepatuhan hukum serta tanggungjawab sosial pada setiap warga negara termasuk penyelenggara negara. memberi rasa aman dan tenteram, mendorong ḱreativitas dan peran aktif masyarakat dalam pembangunan, serta mendukung stabilitas nasional yang mantap dan dinamis:

GBHN 1993, juga memberikan beberapapesan bahwa pembentukan hukum diselenggarakan melalui proses secara terpadu dan demokratis berdasarkan Pancasiladan Undang-Undang Dasar 1945. Dalam rangka itu perlu dindahkan ketentuan yang memenuhi nilai filosofis yang berintikan rasa keadilan dan kebenaran; nilai sosiologis yang sesuai dengan tata nilai budaya yang berlaku dimasyarakat, dan nilai yuridis yang sesuai dengan kaidah-kaidah hukum yang berlaku. Secara khusus diamanatkan bahwa produk hukum kolonial harus diganti dengan produk hukum yang dijiwai dan bersumber pada Pancasila dan Undang-Undang Dasar 1945. Dengan demikian hukum juga hendaknya dapat memberikan payung bagi upaya untuk menciptakan kesejahteraan rakyat yang makin berkeadilan.

\section{Tantangan penegakan hukum}

Dalam rangka menjabarkan berbagai pesan GBHNdalam bidanghukum tersebut kita melihat adanyaberbagai tantangan yang harus kita pecahkan agar dapat menjamin tercapainya tujuan pembangunan nasional. Pengaruh globalisasi sebagai akibat kemajuan ilmu pengetahuan dan teknologi telah menyebabkan terjadinya perubahan dalam upaya pembangunan hukum di Indonesia. Batasan-batasan doktrin hukum yangberlaku telahsemakinkabur. Indonesia tengah dalam proses industrialisasi dan pengintegrasian ekonominya ke dalam 
perekonomiandunia. Dalam proses ini tidak bisa dihindari terjadinya pengintegrasian atau intemasionalisasi dunia usaha nasional dan akan makin banyaknya perusahaanperusahaan multinasional yang turut mengambil bagian dalam proses industrialisasi dan pertumbuhan ekonomi yang makin dipercepat itu. Dapat diperkirakan bahwa proses internasionalisasi ini akan membawa dampak perkembangan hukum di Indonesia.

Dengan demikian sumber daya manusia hukum kita harus dapat ditingkatkan agar mampu mengantisipasi dan menangani masalah-masalah hukum yang makin rumit dan berdimensi global. Kita ingin mandiri dalam bidang hukum, maka kita harus membangun kaum profesi hukum agar dapat memenuhi tantangan itu.

Dalam pembangunan hukum Repelita VI, maka tantangan yang dihadapi adalah bagaimana mengupayakan percepatan pembentukan hukum, dalam arti pembentukan pranatahukum, yang tanggap terhadap dampak globalisasi, dinamika dan aspirasi masyarakat serta dapat mengikuti dan mewadahi perkembangan sosial ekonomi baik di dalam maupun di luar negeri dengan tidak meninggalkan sifat pokok dari hukum yaitu mengatur. Pembentukanhukum nasional harusmampu mengikuti , perkembangan 'hukum internasional yang pesat dengan tetap mengingat akan kepentingan masyarakat dan bangsa Indonesia yang harus senantiasa terlindungi.

Dalam pada itu sasaran pembangunan hukum yang diinginkan padą akhir PJP II adalah terbentuknya sistem hukum nasional yang bersumberkan Pancasiladan Undang-Undang Dasar 1945.
Dewasa ini kita masih memiliki dan harus mengganti produk-produk hukum kolonial, yang selain tidak sesuai lagi dengan keadaan zaman juga tidak mendukúng pembangunan. Produk-produk hukum semacam ini jelas harus dan perlu diganti. Ini merupakan pekerjaan besar yang memerlukan tekad dan kesungguhan hati kita.semua terutama profesi hukum.

.Selanjutnya kesadaran dan ketaatan terhadap hukum yang makin meningkat telah pula menyebabkan adanya peningkatan tuntutan masyarakat terhadap kepastian dan pengayoman hukum yang berintikan keadilan dan kebenaran.

Ditinjau dari sudut strategi pembangunan hukum, maka pembangunan hukum menghadapi tantangan sejauh mana hukum yang diperlukan dapat berperan terhadapperwujudan ketertiban hukum dan kesejahteraan masyarakat terutama daiam mewujudkan program pemerataankeadilan. Timbul dilema di mana pada satu sisi kita memerlukan persatuan dan kesatuan nasional, termasuk satunyahukum nasional yang mengabdi kepada kepentingan nasional. Untuk kebutuhan ini diperlukan strategi pembangunan hukum yang konvensional di mana lembaga-lembaga negara pembuat Undang-undang yaitu Pemerintah dan DPR perananinya mutlak menentukan. Di sisi lain untuk mengakomodasi aspirasi, tuntutan dan dinamika masyarakat, dibutuhkan strategi pembangunan hukum yang responsif di mana dituntut adanya peranan yang lebih besar dari lembaga-lembaga peradilan dan partisipasi masyarakat luas dalam menentukan arah perkembangan hukum yang dianggap penting bagi pelaksanaan keadilan sosial dalam masyarakat, melalui 
putusan hakim (yurisprudensi).

Dalam mewujudkan wibawa hukum pada akhir PJP II, peranan aparat penegak hukum turut menentukan keberhasilannya. Aparat hukum ditantang untuk meningkatkan kualitas manusianya, yang harus tercermin dalam sikap menjunjung tinggi kejujuran, kebenaran dan keadilan, bersih, berwibawa dan bertanggung jawab dalam perilaku keteladanan. Ini juga merupakan suatu tantangan tersendiri.

Merupakan tantangan pula masalah penegakkan disiplin nasional, yang menunjukkan tingkat kesadaran hukum masyarakat. Hal ini erat kaitannya dengan kegiatan penyuluhan dan penerangan hukum,'sehingga anggota masyarakatselain mengetahui hak dan keiwajibannya sebagai warga negara, juga harus terbentuk perilaku yang taat dan patuh pada hukum, yang pada akhirnya akan menunbuhkan dan mengembangkan disiplin nasional.

\section{Kendala-kendala}

Dalam upaya pembentukan pranatapranata hukum yang tanggap menjawab tantangan tersebut diatas kita menghadapi berbagai kendala. Pertama-tama, belum mantapnya koordinasi perencanaan dan pembuatan peraturan perundang-undangan yang terarah dan terpadu, baik dari segi organisasi maupun manajemennya.

Selanjutnya, dalam menghadapi tántangan pembentukan hukum dari sudut Strategi pembangunan hukum yang responsif, kemampuan para hakim dalam menghadapi persoalan hukum baru yang timbul sebagai dampak dari proses internasionalisasi dan sebagai akibat perkembangan ilmu pengetahuan dan teknologi merupakan kendala yang harus kita atasi. Demikian pula kemampuan para hakim untuk mengakomodasikan aspirasi, . tuntutan dan dinamika masyarakat sebagai akibat dari makin tingginya kadarkesadaran hukum masyarakat dalam putusan-putusan yang ditanganinya. Maka upaya untuk meningkatkan mutu sumber daya manusia, khususnya para hakim memerlukan perhatian dalam Repelita VI. .

Dalam bagian akhirmakalah ini, saya ingin menyampaikan suatu pendekatan dalam pembangunan hukum, yang kiranya perlu mendapat perhatian. Sebagaimanakita ketahui bahwa nilai-nilai kegiatan ekonomi suatu bangsa selalu seirama dengan landasan politik dan hukum yang dipergunakan bangsa itu. Maka menjadi tantangan pula bagaimana pembangunan hukum dapat mengantisipasi landasan hukum yang dibutuhkan bangsa Indonesia dalam mendukung pembangunan ekonomi dalam Repelita VI dan PJP II. Saya kira - sudah waktunya kita tidak hanya terpaku pada pendekatan analisis bahasa sematamata untuk bidang hukum, tapi melihat juga kepada pendekatan ilmu lain; dalam hal ini ilmu ekonomi. Yang saya maksud adalah pendekatan kuantitatif dari ilmu ekonomi.

Dengan perpaduan pendekatan analisis bahasa dan analisis kuantitatif, dengan tidak mengurangi sifat dasar dari hukum yaitu mengatur dan menjamin kepastian hukum, maka pembangunan hukum akan dapat menyerap proses perkembangan yang cepat sebagai akibat globalisasi kehidupan dan kemajuan ilmu pengetahuan dan teknologi di samping dinamika dan aspirasi masyarakat yang juga bergerak cepat miengikuti perkembangan sosial ekonomi. 